\title{
Колостоми після обструктивної резекції сигмоподібної кишки. Коли виконувати відновлювальну операцію?
}

\begin{abstract}
Мета роботи: поліпшення результатів реконструктивно-відновлюючих операцій на товстій кишці шляхом визначення оптимальних термінів їх виконання

Матеріали та методи. Проаналізовано результати лікування 152 хворих, яким були виконані реконструктивно-відновлюючі операції. Вивчено гістологічну будову, ендоскопічні зміни кукси прямої кишки в різні терміни після ії відключення, що дозволило встановити оптимальний термін для проведення реконструктивно- відновлюючих операцій.

Результати досліджень та їх обговорення. Аналіз і прогнозування регенераторних процесів в зоні реконструкції кишки в основі своїй базується на результатах морфологічних досліджень. Тому дослідження морфологічних змін проксимального і дистального відділів товстої кишки стало основою для оптимізації термінів виконання реконструктивно-відновлюючих операцій після накладення колостоми. Структурно-функціональна перебудова слизової оболонки починається в проксимальному відділі товстої кишки і в куксі товстої кишки вже через 1 місяць після першого етапу хірургічного лікування і проявляється перевагою гіперпластичних і реактивно-запальних змін, які відновлювалися, за нашими даними, через 3 місяця після накладення стоми. На пізніх термінах дослідження (6 і більше місяців) кукси товстої кишки чітко визначається ряд тенденцій морфофункціональної перебудови товстої кишки. Ці тенденції характеризуються: поступовим і нерівномірним наростанням атрофії крипт з осередковою їх регресією в терміни після 6 місяців і морфофункціональною клітинною перебудовою покривного епітелію. Незважаючи на те, що кількість і довжина крипт зменшується, в пізні терміни після першого етапу хірургічного лікування, їх архітектоніка і клітинний склад зберігається зі значним переважанням келихоподібних клітин. Було проведено ендоскопічне дослідження кукси прямої кишки в різний термін. Аналізуючи ендоскопічну картину кукси товстої кишки, було встановлено, що в терміни 2,5-3 місяці слизова оболонка кукси відповідає нормі, а зі збільшенням терміну відключення товстої кишки відбуваються суттєві зміни стінки товстої кишки, а саме згладжуються складки товстої кишки, знижується тонус стінки кишки, виникають атрофічні зміни слизової оболонки.
\end{abstract}

Ключові слова: реконструктивно-відновлювальні операції; товста кишка; колостома.

Постановка проблеми і аналіз останніх досліджень та публікацій. За останнє десятиріччя як в Україні, так і в світі спостерігається поступове збільшення хворих на рак товстої кишки. Часто єдиним вірним завершенням оперативного лікування (лівобічної геміколектомії або резекції) злоякісних або доброякісних пухлин, травм, запальних процесів лівої половини товстої кишки $€$ формування колостоми [4, 7]. Частіше виведення колостоми відбувається після операцій з приводу пухлини товстої кишки, ускладненої непрохідністю (від 50 \% до 87 \% хворих), перфорацією товстої кишки, флегмоною, перитонітом, параколічним абсцесом, що призводять до тяжкого стану хворого. Ця ситуація не дає можливості виконати первинно-відновлювальну операцію через високий ризик неспроможності анастомозу, який, за різними даними, складає до 15 \% при летальності від 2,5 \% до 4,8 \% [3, 5]. Формування колостоми призводить до інвалідизації хворих, тому реабілітація пацієнтів з колостомою посідає одне 3 центральних місць у структурі соціальних і медичних програм у більшості країн світу. Реконструктивно-відновлювальна операція направлена на відновлення природного пасажу вмісту і повинна забезпечити задовільне функціонування товстої кишки, відновлення морфологічних структур, втрачених під час першої операції. Ця операція реабілітує таких пацієнтів у соціальному, трудовому плані й дозволяє максимально інтегрувати їх у суспільство [6].

Окремі автори [1] пропонують виконувати такі операції в термін від 14 діб до 1 місяця, але більшість фахівців рекомендують ліквідувати колостому в термін від 1 до 4 місяців $[2,8]$. $Є$ також автори, які стверджують, що після операції Гартмана необхідно виконувати реконструктивно-відновлювальні операції в термін 6 міс. - 1 рік [4, 5]. Різноманітність поглядів на цю проблему привела до того, що на сьогодні немає встановлених чітких термінів виконання реконструктивно-відновлювальних операцій і не прослідковані ускладнення в залежності від термінів виконання цих операцій.

Мета роботи: покращити результати реконструктивно-відновлювальних операцій на товстій кишці шляхом визначення оптимальних термінів їх виконання. 
Матеріали і методи. 152 хворим були виконані реконструктивно-відновлювальні операції (PBO) на товстій кишці 3 метою відновлення ї̈ безперервності. Хворі перебували на стаціонарному лікуванні у Вінницькій обласній клінічній лікарні імені М. І. Пирогова та у Військово-медичному клінічному центрі Центрального регіону м. Вінниця за період з 2006 по 2018 рік.

У 98 (64,5 \%) випадках колостоми були сформовані при гострій кишковій непрохідності, причиною якої був рак сигмоподібної кишки, ректосигмоїдного переходу або лівої половини товстої кишки. У 22 (14,5 \%) пацієнтів травми дистальних відділів товстої кишки і промежини, з різних причин, стали приводом до формування колостоми. У 12 (7,9 \%) пацієнтів стоми формували з приводу ускладнень дивертикулярної хвороби сигмоподібної та лівої половини товстої кишки (формування інфільтратів, абсцесів, перитоніт), у 8 (5,3 \%) пацієнтів з неспроможністю швів на товстій кишці після раніше виконаних оперативних втручань, у 7 (4,6 \%) пацієнтів із заворотом сигмоподібної кишки при доліхосигмі з ії̈ некрозом та у 5 (3,2 \%) пацієнтів з перфорацією лівої половини товстої кишки і сигми риб'ячою кісткою оперативне втручання закінчилось формуванням колостоми. Термін від накладання колостоми до госпіталізації з метою виконання РВО був різним і коливався від 1,5 місяця до 2,2 року.

У план обстеження хворих входили лабораторні, біохімічні, бактеріологічні, рентгенологічні, ендоскопічні методи дослідження, метод ультразвукової діагностики органів черевної порожнини, фіброколоноскопія, гістологічне дослідження стінки проксимального відділу товстої кишки та кукси прямої кишки, морфометричне дослідження гістоструктури стінки товстої кишки.

Ми використовували, в основному два види анастомозів “кінець-в-кінець” та “кінець-у-бік” (терміно-латеральний). Анастомоз “бік-у-бік” ми не застосовували. Розподіл за видами анастомозу: сигмо-ректоанастомоз сформований у 84 (55,3 \%), десцендо-ректоанастомоз - у 34 (22,4 \%), трансверзо-ректоанастомоз - у 24 (15,8 \%), трансверзосигмоанастомоз - у 10 (6,5 \%) пацієнтів. Товстокишкові анастомози формували ручним способом дворядними швами атравматичною голкою № 3 у 141 (92,7\%) пацієнта, апаратним способом анастомоз сформований в $11(7,3 \%)$ випадках.

54 (35,5 \%) хворих були оперовані з приводу непухлинних захворювань товстої кишки: у 22 пацієнтів стома формувалась без явищ перитоніту або в умовах обмеженого перитоніту - у цих пацієнтів запальні явища зникають дещо раніше, ніж 3 місяці; у 32 хворих, оперованих з різних причин в умовах дифузного або розлитого перитоніту, ліквідувати колостому і виконувати РВО технічно складніше. Запальний процес у черевній порожнині, розташування дренажів, тривалий парез у післяопераційному періоді сприяють розвитку великої кількості спайок, зрощень тканин, а інколи інфільтратів і абсцесів черевної порожнини, тому до закриття колостоми та виконання РВО таким хворим слід підходити особливо виважено. Тому ми рекомендуємо виконувати РВО таким пацієнтам пізніше, не раніше 3-3,5 місяця.

Результати досліджень та їх обговорення. 152 пацієнти з колостомами були поділені на 2 групи: I - група порівняння, до якої увійшли 68 хворих (45,4 \%), прооперованих з 2006 по 2012 рр. (цим пацієнтам проводився стандартний комплекс обстежень та лікування); II - основна група, до якої увійшли 84 хворих (54,6 \%) зі стомами, які були прооперовані з 2012 по 2018 рік. Пацієнти обох груп були зіставними за статтю, віком, причинами виведення стом. В основній групі ми застосовували розроблену передопераційну підготовку кукси прямої кишки з оцінкою еубіозу та прогнозуванням можливості неспроможності швів анастомозу.

Через 1 місяць після першого етапу хірургічного лікування при гістологічному дослідженні слизової оболонки (СО) проксимального відділу товстої кишки (в ділянці колостоми) було виявлено переважання гіперпластичного та дистрофічно-запального компонентів. Поверхневий епітелій слизової оболонки (СО) місцями був десквамований, кількість келихоподібних епітеліоцитів (KЕ) вогнищево збільшувалася, крипти поглиблювалися, проміжки між ними скорочувалися, в субепітеліальних відділах траплялися поодинокі лімфоцити та сегментоядерні лейкоцити. В ділянці кукси товстої кишки через 1 місяць після першого етапу хірургічного лікування клітинний склад крипт характеризувався збереженням типової архітектоніки товстої кишки: постійні стовпчасті епітеліоцити (СЕ), недиференційовані та ендокринні клітини. При цьому помічено, що до 3 місяців чітко зростає вміст келихоподібних клітин на всьому протязі крипт, з наступним осередковим їх зменшенням після 6 місяців. Ретикулярна строма слизової оболонки на цьому терміні дослідження характеризується нерівномірним набряком, осередковою клітинною інфільтрацією, причому ступінь виразності і характер клітинного інфільтрату варіює.

Досліджуючи динаміку морфологічних змін у стінці товстої кишки в ділянці колостоми ми ви- 
явили, що через 3 місяці після операції в слизовій оболонці гіперпластичні зміни зменшувалися у 92,2 \% пацієнтів, це проявлялося відновленням глибини крипт $((0,547 \pm 0,04)$ мм проти $(0,951 \pm 0,01)$ мм після першого місяця, $\mathrm{p}<0,001)$ та збереженням продукції муцинів з переважно внутрішньоклітинною їх секрецією. Також у цей термін відзначається виражене зниження проявів запальної реакції стінки товстої кишки й відновлення лімфогістіоцитарного шару слизової оболонки, тобто ії гістологічна характеристика наближається до характеристики слизової оболонки незміненої стінки товстої кишки.

Через 6 та більше місяців з моменту першого етапу хірургічного лікування патоморфологічні зміни проксимального відділу товстої кишки суттєво не відрізнялися від патоморфологічних змін, які виникали через 3 місяці. Лише у 23 хворих виявлено вогнищеву гіпотрофію м'язового шару 3 початковими явищами атрофії СО товстої кишки та подальшим збільшенням кількості фібробластів, що підтверджувалося даними морфометричного дослідження. Після 6 місяців в дистальному відділі товстої кишки гістологічна архітектоніка СО була збережена, попри прогресування атрофічних змін. При цьому виявлено значну перебудову СО товстої кишки зі зміною клітинного диференціювання, визначалися зниження або відсутність стовпчастих епітеліоцитів і переважання келихоподібної диференціації із секрецією сіаломуцинів, що мають пристосувальний і захисний характер. У терміні з 3 до 6 місяців після операції за типом Гартмана в стінці кукси товстої кишки прогресували дистрофічні зміни поверхневого епітелію та крипт. У 13,15 \% хворих після трьох місяців та в 17,1 \% після шести місяців після операції за типом Гартмана спостерігалось кістоподібне розширення залоз. При сталості й тенденції до наростання морфологічних проявів атрофії крипти зберігали архітектоніку, близьку до типової для незміненого товстого кишечника.

Під час ендоскопічного дослідження кукси товстої кишки було виявлено, що в термін 1 місяць втрачається чіткість судинного малюнка, на слизовій виникають ділянки гіперемії та набряку, петехії, поступово до цих змін стінки товстої кишки на фоні загального запалення слизової оболонки додаються геморагії на слизовій, нашарування фібрину та окремі ділянки некрозу слизової. Всі вищевказані зміни слизової кукси прямої кишки через 1 місяць після операції свідчать про запалення стінки товстої кишки.

Ендоскопічно слизова оболонка кукси товстої кишки в термін 3 місяці після операції за типом
Гартмана наближається до норми, що проявляється блідо-рожевим кольором слизової, чіткістю судинного малюнка, відсутністю ознак запалення. Зі збільшенням терміну відключення товстої кишки більше згладжуються її складки, відмічається блідість судинного малюнка, знижується тонус стінки кишки, виникають атрофічні зміни слизової оболонки.

Запальні та атрофічні зміни в стінці товстої кишки збільшували ризик виникнення неспроможності швів анастомозу, що спостерігалося у 13 (8,6 \%) пацієнтів обох груп без явищ поширеного перитоніту (часткова неспроможність) і всі пацієнти не потребували повторних операцій. Неспроможність швів виникала, як правило, на 5-8 добу після операції. Промивна система антисептиками і ізотонічним розчином натрію хлориду була налагоджена через тазові дренажі. На 16-21 добу неспроможність ліквідували у 11 хворих, у 2 хворих - через 1 місяць.

У групі порівняння в 2 (1,3\%) пацієнтів виник частковий некроз товстої кишки з перитонітом, що потребувало релапаротомії і формування повторної колостоми. Повна неспроможність на 8-10 добу виникла в 1 пацієнта внаслідок надмірної скелетизації привідної ділянки кишки, у іншого - внаслідок тромбозу судин брижі і, як наслідок, її некрозу. Летальних наслідків, як у групі порівняння, так і в основній групі, не було. Всі повторно прооперовані пацієнти видужали і були виписані додому в задовільному стані.

Висновки. 1. У хворих після операції Гартмана, оперованих з приводу травми і захворювань товстої кишки без явищ перитоніту, оптимальним терміном для виконання РВО на товстій кишці $€$ 2,5-3 місяці, з явищами перитоніту - 3-3,5 місяця. Хворим, яким виконувалась обструктивна резекція сигмоподібної кишки з приводу пухлини, виконання реконструктивно-відновлювальної операції можливе в термін 3 місяці, але, враховуючи необхідність отримання різних курсів хіміо-, променевої терапії, його необхідно відстрочити до 6 місяців, з обов’язковим ретельним обстеженням на предмет прогресування онкологічного процесу і метастазування.

2. Усунення колостоми з відновленням пасажу кишкового вмісту - це психологічно, соціально та економічно обгрунтована реабілітація стомованих хворих.

3. У разі виникнення часткової неспроможності швів анастомозу необхідно налагодити промивну систему і двічі або тричі на добу проводити перев’ язки з антисептиками. 


\section{З ДОСВІДУ РОБОТИ}

\section{СПИСОК ЛІТЕРАТУРИ}

1. Косован В. М. Відновлювальні операції після перенесених обструктивних резекцій сигмоподібної кишки в ранні терміни / В. М. Косован // Вісник Вінницького національного медичного університету. - 2010. - № 14 (1). - С. 119-122.

2. Пойда А. И. Реконструктивно-восстановительные операции в хирургии толстой кишки / А. И. Пойда // Здоровье Украины. - 2009. - № 21/1. - С. 44-45.

3. Пойда О. І. Неспроможність швів анастомозів в хірургії товстої кишки / О. І. Пойда, В. М. Мельник // Украинский журнал хирургии. - 2011. - № 2. - С. 44-47.

4. Маметкулієв Б. Р. Оптимізація результатів реконструктивно-відновлюючих операцій при обструктивних резекціях товстої кишки з урахуванням профілактики гнійно-септичних ускладнень / Б. Р. Маметкулієв // Актуальні питання транспортної медицини - 2013. - № 1. - С. 97 - 107.

5. Реконстуктивно-восстановительные операции в колопрок-

\section{REFERENCES}

1. Kosovan, V.M. (2010). Vidnovliuvalni operatsii pislia perenesenykh obstruktyvnykh rezektsii syhmopodibnoi kyshky v ranni terminy [Reconstructive operations after suffering obstructive resection of the sigmoid colon in the early stages]. Visnyk Vinnytskoho natsionalnoho medychnoho universytetu - Bulletin of Vinnytsia National Medical University, 14 (1), 119-122 [in Ukrainian].

2. Poyda, A.I. (2009). Rekonstruktivno-vosstanovitelnye operatsii v khirurgii tolstoy kishki [Reconstructive restorative in colon surgery]. Zdorovye Ukrainy - Health of Ukraine, 12 (1), 44-45 [in Russian].

3. Poida, O.I., \& Melnyk, V.M. (2011). Nespromozhnist shviv anastomoziv $\mathrm{v}$ khirurhii tovstoi kyshky [Failure of anastomosis sutures in colon surgery]. Ukrainskyi zhurnal khyrurhii - Ukrainian Journal of Surgery, (2), 44-47 [in Ukrainian].

4. Mametkuliiev, B.R. (2013). Optymizatsiia rezultativ rekonstruktyvno-vidnovliuiuchykh operatsii pry obstruktyvnykh rezektsiiakh tovstoi kyshky z urakhuvanniam profilaktyky hniino-septychnykh uskladnen [Optimization of the results of reconstructive operations for obstructive bowel diseases and profitable septic complications]. Aktualni pytannia transportnoi medytsyny - Actual Issues of Transport Medicine, (1), 97-107 [in Ukrainian].

5. Tamm, T.I., Datsenko, B.M., Belov, S.G., \& Kirillov, A.V. (2010) Rekonstruktivno-vosstanovitelnye operatsii V ko- тологии / Т. И. Тамм, Б. М. Даценко, С. Г. Белов, А. В. Кириллов // Хірургічна перспектива. - 2010. - № 1. - С. 173-175. 6. Захараш М. П. Выбор метода восстановительного этапа операции при хирургическом лечении колоректального рака / М. П. Захараш, А. И. Пойда, В. М. Мельник // Материалы III съезда колопроктологов Украины с участием стран Центральной и Восточной Европы. - Одесса, 2011. - С. 257-259. 7. Коцубанов К. В. Морфо-функциональное состояние отключенной толстой кишки в развитии послеоперационного пареза при восстановительных операциях / К. В. Коцубанов, С. В. Ярощак, А. О. Миминошвили // Украинский журнал хирургии. - 2011. - № 1. - С. 136-139.

8. Шапринський В. О. Вибір оптимального терміну виконання реконструктивно-відновлюючих операцій на товстій кишці / В. О. Шапринський, С. М. Шалигін // Клінічна анатомія та оперативна хірургія. - 2012. - № 3. - С. 106-107.

loproktologii [Reconstructive surgery in coloproctology]. Khirurgichna persperspektiva - Surgical Perspective, (1), 173175 [in Russian].

6. Zakharash, M.P., Zakharash, M.P., Poyda, A.I., \& Melnik, V.M. (2011). Vybor metoda vosstanovitelnogo etapa operatsii pri khirurgicheskom lechenii kolorektalnogo raka [The choice of the method of the recovery phase of the operation in the surgical treatment of colorectal cancer]. Proceedings of the $3^{\text {rd }}$ Congress of coloproctologists of Ukraine with the Participation of Countries of Central and Eastern Europe. Odessa, May 18-20. (pp. 257-259) [in Russian].

7. Kotsubanov, K.V., Yaroshchak, S.V., \& Miminoshvili, A.O. (2011). Morfo-funktsionalnoe sostoyanie otklyuchennoy tolstoy kishki v razvitii posleoperatsionnogo pareza pri vosstanovitelnykh operatsiyakh [Morphological and functional state of the disabled colon in the development of postoperative paresis during recovery operations]. Ukrainskyi zhurnal khirurhii - Ukrainian Journal of Surgery, (1), 136-139 [in Russian].

8. Shaprynskyi, V.O., \& Shalyhin, S.M. (2012). Vybir optymalnoho terminu vykonannia rekonstruktyvno-vidnovliuiuchykh operatsii na tovstii kyshtsi [The choice of the optimal term for reconstructive surgery on the colon]. Klinichna anatomiia ta operatyvna khirurhiia - Clinical Anatomy and Surgery, (3), 106-107 [in Ukrainian]. 


\title{
COLOSTOMY AFTER OBSTRUCTIVE RESECTION OF THE SIGMOID COLON. WHEN TO PERFORM A RESTORATIVE OPERATION?
}

\begin{abstract}
The aim of the work: improvement of the results of reconstructive restorative operations of colon by determining the optimal timing of their implementation.

Materials and Methods. Treatment results of 152 patients, who underwent reconstructive restorative operations were analysed. Histopathologic structure, endoscopic changes of the rectal stump on the different terms after its disconnection were studied. It allowed us to establish the optimal time for reconstructive restorative operation.

Rresults and Discussion. Analysis and prognosis of regenerative processes in the area of bowel reconstruction is based on the results of morphological studies. Therefore, studies of morphological changes in the proximal and distal colon became the basis for optimizing the timing of reconstructive restorative operations after colostomy. Structural and functional restructuring of the mucous membrane begins in the proximal colon and in the colon stump 1 month after the first phase of surgical treatment and is manifested by the advantage of hyperplastic and reactive-inflammatory changes, which were restored, according to our data, 3 months after stoma application. In the later stages of the research (6 months or more) of the colon stump, a number of trends in the morphofunctional restructuring of the colon are clearly defined. These trends are characterized by a gradual and uneven increase in crypt atrophy with focal regression after 6 months and morphofunctional cell remodeling of the integumentary epithelium. Despite the fact that the number and length of crypts decreases, in the later stages after the first phase of surgical treatment, their architectonics and cellular composition is preserved with a significant predominance of goblet cells. An endoscopic examination of the rectal stump was held at different times. Analyzing the endoscopic picture of the stump of the colon, it was found that in the period of 2.5-3 months the mucous membrane of the stump corresponds to the norm. With an increase of the period of disconnection of the colon, significant changes in the colon wall occur, namely, the folds of the colon are smoothed out, the tone of the wall of colon decreases, arrise atrophic changes in the mucous membrane.
\end{abstract}

Key words: reconstructive restorative operations; colon; colostomy.

В. А. ШАПРИНСКИЙ, А. В. ВЕРБА, С. М. ШАЛЫГИН, Е. В. ШАПРИНСКИЙ, И. П. МАРЦИНКОВСКИЙ, О. О. ВОРОВСКИЙ, А. И. ЧЕРНИЧЕНКО

Винницкий национальный медицинский университет имени Н. И. Пирогова

\section{КОЛОСТОМЫ ПОСЛЕ ОБСТРУКТИВНОЙ РЕЗЕКЦИИ СИГМОВИДНОЙ КИШКИ. КОГДА ПРОВОДИТЬ ВОССТАНОВИТЕЛЬНУЮ ОПЕРАЦИЮ?}

Цель работы: улучшение результатов реконструктивно-восстановительных операций на толстой кишке путём определения оптимальных сроков их выполнения.

Материалы и методы. Проанализировано результаты лечения 152 больных, которым были выполнены реконструктивно-восстановительные операции. Изучено гистологическое строение, эндоскопические изменения культи прямой кишки в разные сроки после её отключения, что позволило установить оптимальный срок для проведения реконструктивно-восстановительных операций.

Результаты исследований и их обсуждение. Анализ и прогнозирование регенераторных процессов в зоне реконструкции кишки в основе своей базируется на результатах морфологических исследований. Поэтому исследование морфологических изменений проксимального и дистального отделов толстой кишки стало основой для оптимизации сроков выполнения реконструктивно-восстановительных операций после наложения колостомы. Структурно-функциональная перестройка слизистой оболочки начинается в проксимальном отделе толстой кишки и в культе толстой кишки уже через 1 месяц после первого этапа хирургического лечения и проявляется преимуществом гиперпластических и реактивно-воспалительных изменений, которые восстанавливались, по нашим данным, через 3 месяца после наложения стомы. На поздних сроках исследования (6 и более месяцев) культи толстой кишки четко определяется ряд тенденций морфофункциональной перестройки толстой кишки. Эти тенденции характеризуются постепенным и неравномерным нарастанием атрофии крипт с их очаговой регрессией в сроки после 6 месяцев и морфофункциональной клеточной перестройкой покровного эпителия. Несмотря на то, что количество и длина крипт в поздние сроки после первого этапа хирургического лечения уменьшаются, их архитектоника и клеточный состав сохраняется, со значительным преобладанием бокаловидных клеток. Было проведено эндоскопическое исследование культи прямой кишки в разные сроки. Анализируя эндоскопическую картину культи толстой кишки, было установлено, что в сроки 2,5-3 месяца слизистая оболочка культи соответствует норме, а с увеличением срока отключения толстой кишки, происходят существенные изменения ее стенки, а именно сглаживаются складки толстой кишки, снижается тонус стенки кишки, возникают атрофические изменения слизистой оболочки.

Ключевые слова: реконструктивно-восстановительные операции; толстая кишка; колостома. 